\title{
EFFECT OF ADDING MICROBIAL LIPASE ON THE ACCELERATION OF UF-RAS CHEESE RIPENING
}

\author{
Shaimaa M. Hamdy, H. Sh. Abdel Montaleb, Kh. A. Abbas, \\ Ratiba A. Beyomi and M. A. Degheidi \\ Dairy Dept., Fac. of Agric., Fayoum Univ., BP 6300 Fayoum, Egypt. \\ Corresponding author: shaimahamdy@hotmail.com
}

Received: Oct. 1, 2016

Accepted: Oct. 10,2016

\begin{abstract}
The effect of adding microbial lipase enzyme to UF cheese milk $(0,50.000$, 100.000 , and 150.000 lipase units $/ 15 \mathrm{~kg}$ retentate) on some chemical, rheological, and sensory characteristics of UF-Ras cheese was studied during the 3 months of ripening. The obtained results indicated that lipase enzyme caused a little effect on the gross composition of cheese during ripening. The level of lipolysis and proteolysis were significantly $(p<0.05)$ higher in the experimental cheeses than those of the control cheese during ripening, which means that there are a positive effect of lipase on ripening time. Lipase addition led to increase the rate of liploysis process about $30 \%$ in 60 days and treated cheeses of this age had TVFA levels typical of 90 days of untreated cheeses. Moreover, enzyme-treated cheese had harder texture than untreated cheeses of the same age. Sensory evaluation showed a significant difference in the total scores of the experimental and control cheeses, with significantly lower-quality scores for the cheeses treated with 100.000 and $150.000 \mathrm{u} / 15 \mathrm{~kg}$ retentate. Cheeses with the highest level of lipase pronounced bitter taste at 60 days of ripening. The most acceptable cheeses were the UF Ras cheese treated with lipase $50.000 \mathrm{U} / 15 \mathrm{~kg}$ retentate, which was a slightly similar to the control cheeses at 60 days of ripening.
\end{abstract}

Key Words: Accelerated cheese ripening; lipolysis in cheese, ultrafiltration, Ras cheese.

\section{INTRODUCTION}

Ras cheese produced by ultrafiltration has many advantages on the economical, technological and nutritional levels. On the other hand, UF-Ras cheese was characterized by slower ripening, hard texture and lack of flavor than traditional ones (El-Shibiny et al., 1991). In order to take the advantage of ultrafiltration in Ras cheese manufacture, it is indispensable to accelerate the ripening process and reactions included which reflect on the flavor and texture of the resultant cheese.

Exogenous lipases (glycerol ester hydrolases EC 3.1.1.3) were extensively used in the acceleration of cheese ripening and to develop the distinctive flavor of cheese variety (Fox, 1993, Azarnia et al., 2006, Aravindan et al., 2007, Hernández et al., 2009, El-Hofi et al., 2011, Abou-zeid, 2015). Considerable attention has been given to accelerating traditional Ras cheese ripening by addition of lipases (El-Shibiny et al., 1990, El-Soda et al., 1990, Hassan et al., 1996, Ismail et al., 1996).

In this concern, microbial lipase enzyme was used to investiagte its effect on the acceraltion of the ripening process in a trial to improve the flavor and texture qualities of Egyptian UF-Ras cheese during the ripning period.

\section{MATERIALS AND METHODS}

\section{Materials}

Cow's milk was supplied by a private farm in Fayoum governorate, Egypt. Rennet powder (CHY-MAX, $2280 \mathrm{IMCU} / \mathrm{ml}$, Ch. Hansen, Denmark), a yoghurt starter (DVS YC-X11) was obtained from Chr. Hansen's Laboratory (Copenhagen, Denmark). Calcium chloride and sodium chloride were obtained from a local market in Egypt. Microbial lipase from oligosporus strains Rhizopus was obtained from the culture 
collection of laboratory of Biotechnology, Department of Botany, GC University Faisalabad, Pakistan. Experimental cheeses were produced in our pilot dairy plant of Fac. of Agric., of Fayoum Univ., Egypt.

\section{UF-Ras cheese manufacturing and sampling}

Four batches of cheese were made on the same day from ultrafiltered cow's milk (concentration X2). One batch of cheeses was used to produce UF-Ras cheese without enzyme addition (as Control), while the other three batches were separately mixed with microbial lipase prior coagulation at a ratio $50.000,100.000,150.000 \mathrm{U} / 15 \mathrm{~kg}$ of retentate, respectively. Coagulation by rennet addition $(2 \mathrm{~g} / 100 \mathrm{~kg})$ and the procedure of cheese making was followed as described by El-Shibiny et al. (1991). Cheese ripening took place at $12^{\circ} \mathrm{C}$ and a relative humidity of $90-95 \%$ for 90 days. Cheeses were sampled in triplicate after salting stage (10-day-old cheese) and at 15 , 30,60 and 90 days of the ripening period for some chemical composition, sensorial characteristics and at 30,60 and 90 days for textural characteristics.

\section{Physiochemical analysis}

Grated cheese samples were analysed for their acidity $\%$, moisture $\%$, protein $\%$, fat $\%, W S N / T N \%$ and NPN/TN\% contents according to AOAC (2005). TVFA was determined by steam distillation method according to Kosikowski (1966). All analyses were performed in triplicate and results reported as means \pm standard deviations.

\section{Texture profile analysis (TPA)}

Cylindrical cheese samples were compressed to $20 \%$ of the original height of the sample in two bites on a universal Testing machine (TL-Pro, Food Technology Corporation, Sterling, Virginia, USA) provided with software at a rate of 60 $\mathrm{mm} / \mathrm{sec}$, force $1 \mathrm{~N}$ at room temperature. The following parameters were evaluated according to the definitions given by the
International Dairy Federation (Federation, 1991): Hardness (N), Cohesiveness ( ), Springiness $(\mathrm{mm})$, Gumminess $(\mathrm{N})$, Chewiness (N.mm).

\section{Sensory analysis}

Cheese samples were evaluated for flavour, body and texture by the staff members at Dairy Department, Agricultural Faculty of Fayoum University according to the scoring sheet of El-Shibiny et al., (1991).

\section{Statistical analysis}

All data were expressed as mean values \pm standard deviations and analyzed using on way analysis of variance (ANOVA) followed by the least significant differences (LSD) test at significant $(P<0.05)$ using XLSTAT statistical software.

\section{RESULTS AND DISCUSSION Chemical composition of UF Ras cheese.}

The chemical composition of the control and experimental UF Ras cheeses is given in Table (1). Significant differences were observed between the control and experimental UF cheeses. The lipasetreated cheeses had a significantly lower moisture content and higher titratable acidity contents as compared to the control cheeses $(P<0.05)$. Consequently, lipasetreated UF cheeses had higher protein and fat contents than that of the control cheeses. The high titratable acidity contents of the lipase-treated cheese samples due to the accumulation of free fatty acids with the action of lipase as reviewed by Ozcan and Kurdal (2012a). This increase was affected clearly by the amount of added enzyme to UF cheese milk. Thus, the cheese samples with higher acidity tend to be denser in structure whereas the lower acidity cheeses tend to absorb more water as reviewed by Karami et al. (2009) therefore, the control cheese samples had more water. Based on the accelerated lipolysis by the added lipase, some fat globules were hydrolysed 
and therefore the number of fat globules decreased in treated samples (Karami et al., 2009), which is not the case of control samples. During the ripening, a slight decrease of fat in dry matter can be noticed. This decrease, more noticeable at the end of ripening period, is due to the lipolysis process. There were no significant differences $(P<0.05)$ in the fat on dry matter content of the tested samples. These results are in agreement with ( Hassan et al., 1996, Ozcan and Kurdal, 2012b, Abou-zeid, 2015).

Table 1: Effect of adding microbial lipase on some chemical composition (mean \pm SD) of UF-Ras cheese during ripening periods.

\begin{tabular}{|c|c|c|c|c|c|}
\hline & & Treatments & & & \\
\hline Parameters & $\begin{array}{l}\text { Ripening } \\
\text { periods } \\
\text { (days) }\end{array}$ & Control & $\begin{array}{l}\text { Lipase } \\
\text { (50.000U) }\end{array}$ & $\begin{array}{c}\text { Lipase } \\
\text { (100.000U) }\end{array}$ & $\begin{array}{c}\text { Lipase } \\
(150.000 \mathrm{U})\end{array}$ \\
\hline \multirow{4}{*}{ Acidity\% } & 15 & $1.20 \pm 0.09^{c}$ & $1.34 \pm 0.05^{\mathrm{b}}$ & $1.93 \pm 0.03^{\mathrm{a}}$ & $1.96 \pm 0.05^{\mathrm{a}}$ \\
\hline & 30 & $1.32 \pm 0.04^{\mathrm{c}}$ & $1.38 \pm 0.07^{c}$ & $2.48 \pm 0.07^{b}$ & $2.63 \pm 0.03^{\mathrm{a}}$ \\
\hline & 60 & $1.51 \pm 0.02^{d}$ & $1.81 \pm 0.02^{\mathrm{C}}$ & $3.22 \pm 0.19^{b}$ & $3.86 \pm 0.17^{\mathrm{a}}$ \\
\hline & 90 & $1.92 \pm 0.02^{c}$ & $2.54 \pm 0.05^{\mathrm{b}}$ & $3.79 \pm 0.18^{\mathrm{a}}$ & $3.94 \pm 0.25^{\mathrm{a}}$ \\
\hline \multirow{4}{*}{ Moisture\% } & 15 & $37.49 \pm 0.15^{\mathrm{a}}$ & $36.57 \pm 0.15^{b}$ & $35.92 \pm 0.51^{c}$ & $35.34 \pm 0.09^{d}$ \\
\hline & 30 & $34.76 \pm 0.17^{\mathrm{a}}$ & $33.73 \pm 0.07^{\mathrm{b}}$ & $32.78 \pm 0.14^{c}$ & $31.67 \pm 0.17^{d}$ \\
\hline & 60 & $32.56 \pm 0.45^{a}$ & $31.60 \pm 0.55^{b}$ & $30.54 \pm 0.58^{c}$ & $29.34 \pm 0.11^{d}$ \\
\hline & 90 & $31.35 \pm 0.23^{\mathrm{a}}$ & $28.71 \pm 0.07^{b}$ & $26.59 \pm 0.15^{\mathrm{C}}$ & $25.10 \pm 0.04^{d}$ \\
\hline \multirow{4}{*}{ Fat \% } & 15 & $37.17 \pm 0.29^{b}$ & $38.08 \pm 0.14^{\mathrm{a}}$ & $37.33 \pm 0.29^{b}$ & $38.25 \pm 0.25^{\mathrm{a}}$ \\
\hline & 30 & $37.67 \pm 0.29^{b}$ & $38.28 \pm 0.30^{\mathrm{ab}}$ & $38.42 \pm 0.52^{\mathrm{a}}$ & $38.75 \pm 0.43^{\mathrm{a}}$ \\
\hline & 60 & $38.67 \pm 0.58^{c}$ & $39.02 \pm 0.78^{c}$ & $40.33 \pm 0.29^{b}$ & $41.42 \pm 0.52^{\mathrm{a}}$ \\
\hline & 90 & $39.88 \pm 0.68^{b}$ & $40.58 \pm 0.63^{b}$ & $42.25 \pm 0.43^{\mathrm{a}}$ & $42.65 \pm 0.61^{\mathrm{a}}$ \\
\hline \multirow{4}{*}{$\begin{array}{c}\text { Fat/dry matter } \\
\%\end{array}$} & 15 & $59.46 \pm 0.34^{a}$ & $60.04 \pm 0.17^{\mathrm{a}}$ & $58.26 \pm 0.91^{\mathrm{b}}$ & $59.16 \pm 0.47^{\mathrm{ab}}$ \\
\hline & 30 & $57.74 \pm 0.49^{a}$ & $57.77 \pm 0.50^{a}$ & $57.17 \pm 0.87^{\mathrm{a}}$ & $56.71 \pm 0.76^{\mathrm{a}}$ \\
\hline & 60 & $57.33 \pm 0.48^{b}$ & $57.04 \pm 0.72^{\mathrm{b}}$ & $58.07 \pm 0.25^{\mathrm{ab}}$ & $58.61 \pm 0.75^{a}$ \\
\hline & 90 & $58.10 \pm 1.18^{a}$ & $56.93 \pm 0.86^{a}$ & $57.56 \pm 0.71^{\mathrm{a}}$ & $56.94 \pm 0.83^{\mathrm{a}}$ \\
\hline \multirow{4}{*}{ Protein \% } & 15 & $19.91 \pm 0.00^{b}$ & $19.46 \pm 0.00^{\mathrm{C}}$ & $19.93 \pm 0.04^{b}$ & $20.33 \pm 0.04^{a}$ \\
\hline & 30 & $21.69 \pm 0.00^{b}$ & $21.84 \pm 0.52^{b}$ & $22.44 \pm 0.26^{\mathrm{a}}$ & $22.73 \pm 0.26^{\mathrm{a}}$ \\
\hline & 60 & $21.99 \pm 0.26^{c}$ & $22.29 \pm 0.26^{\mathrm{c}}$ & $22.88 \pm 0.26^{b}$ & $23.63 \pm 0.26^{\mathrm{a}}$ \\
\hline & 90 & $24.07 \pm 0.26^{c}$ & $24.22 \pm 0.26^{c}$ & $24.97 \pm 0.26^{\mathrm{b}}$ & $26.01 \pm 0.26^{a}$ \\
\hline
\end{tabular}




\section{Cheese proteolysis and lipolysis}

Lipase treated cheeses exhibited noticeable differences in the proteolysis and lipolysis rates of UF-Ras cheeses during the ripening compared to the control cheese. Proteolysis increased with ripening and with increasing enzyme concentration in treated UF cheese. As shown in Table (2); the levels of WSN/TN\%, and NPN/TN\% in the control cheese were significantly lower than those of the corresponding lipase-treated cheeses during the ripening periods which is in accordance with the results obtained by (Karami et al., 2009, Ozcan and Kurdal, 2012b). Higher levels of primary proteolysis in lipase-treated cheeses may be attributed to the enzyme activity of lipase which in somewhat enhanced the proteolysis of cheese during ripening as reported by (Omar et al., 1986, Kheadr et al., 2002). El Neshawy et al. (1983) reported increases in the WSN\% when treating milk with two different lipases in the manufacture of Domiati cheese, possibly due to higher levels of protease contamination in the enzyme preparations used.
The extent of lipolysis, as assessed by the TVFA, was determined for all UF cheese samples (Table 2) during the ripening periods. The TVFA contents of all samples significantly $(p<0.05)$ increased during the progress of cheese ripening. This reflects continuous hydrolysis of lipid fraction in cheese during the ripening period. There were significantly higher levels of lipolysis in treated cheeses as compared to the control cheese (Table 3). Lipase-treated cheeses exhibited noticeable differences in their TVFA levels compared to the control cheeses, indicating that increasing of the lipolysis of triglycerides and the production of free fatty acids with addition of lipase.

The obtained results suggest that an increase in proteolysis and lipolysis in treated UF cheese samples over that of the control during the ripening which indicates an acceleration of the cheese ripening take place when lipase was added. Thus, the cheeses made with lipase exhibited the same TVFA content at 30 days as similar in control cheeses at 60 days.

Table 2: Effect of adding microbial lipase on the lipolysis (TVFA) and proteolysis index (mean \pm SD) of UF-Ras cheese during ripening.

\begin{tabular}{|c|c|c|c|c|c|}
\hline \multicolumn{6}{|c|}{ Treatments } \\
\hline Parameters & $\begin{array}{c}\text { Ripening periods } \\
\text { (days) }\end{array}$ & Control & $\begin{array}{c}\text { Lipase } \\
(50.000 U)\end{array}$ & $\begin{array}{c}\text { Lipase } \\
(100.000 U)\end{array}$ & $\begin{array}{c}\text { Lipase } \\
(150.000 U)\end{array}$ \\
\hline \multirow{4}{*}{$\begin{array}{c}\text { TVFA } \\
\text { (as } \mathrm{ml} \text { of } 0.1 \mathrm{~N} \\
\text { Naot/10g cheese }\end{array}$} & 15 & $54.00 \pm 1.00^{d}$ & $60.00 \pm 1.00^{c}$ & $85.00 \pm 1.00^{b}$ & $102.00 \pm 1.00^{\mathrm{a}}$ \\
\hline & 30 & $55.00 \pm 0.2^{d}$ & $64.00 \pm 0.2^{c}$ & $91.00 \pm 0.2^{b}$ & $122.00 \pm 0.2^{\mathrm{a}}$ \\
\hline & 60 & $59.00 \pm 1.00^{c}$ & $79.00 \pm 1.00^{c}$ & $98.00 \pm 1.00^{b}$ & $144.00 \pm 1.00^{\mathrm{a}}$ \\
\hline & 90 & $91.00 \pm 1.00^{d}$ & $96.00 \pm 1.00^{\mathrm{c}}$ & $122.00 \pm 1.00^{b}$ & $166.00 \pm 1.00^{a}$ \\
\hline \multirow{4}{*}{ WSN/TN\% } & 15 & $8.76 \pm 0.65^{b}$ & $8.91 \pm 0.62^{\mathrm{ab}}$ & $9.71 \pm 0.49^{a b}$ & $9.83 \pm 0.50^{\mathrm{a}}$ \\
\hline & 30 & $10.39 \pm 0.45^{d}$ & $11.30 \pm 0.10^{c}$ & $12.09 \pm 0.55^{\mathrm{b}}$ & $13.19 \pm 0.32^{\mathrm{a}}$ \\
\hline & 60 & $12.19 \pm 0.32^{b}$ & $12.98 \pm 0.30^{b}$ & $13.94 \pm 0.58^{\mathrm{a}}$ & $14.08 \pm 0.55^{a}$ \\
\hline & 90 & $13.78 \pm 0.40^{c}$ & $14.84 \pm 0.31^{\mathrm{b}}$ & $15.16 \pm 0.45^{\mathrm{b}}$ & $16.11 \pm 0.26^{a}$ \\
\hline \multirow{4}{*}{ NPN/TN\% } & 15 & $5.15 \pm 0.26^{b}$ & $5.73 \pm 0.27^{\mathrm{a}}$ & $5.74 \pm 0.25^{a}$ & $6.07 \pm 0.26^{a}$ \\
\hline & 30 & $6.37 \pm 0.12^{d}$ & $6.81 \pm 0.10^{c}$ & $7.16 \pm 0.03^{b}$ & $7.52 \pm 0.08^{\mathrm{a}}$ \\
\hline & 60 & $6.90 \pm 0.33^{\mathrm{C}}$ & $7.27 \pm 0.13^{\mathrm{bc}}$ & $7.60 \pm 0.17^{\mathrm{ab}}$ & $7.99 \pm 0.27^{\mathrm{a}}$ \\
\hline & 90 & $6.92 \pm 0.25^{\mathrm{c}}$ & $7.49 \pm 0.26^{b}$ & $7.68 \pm 0.09^{\mathrm{ab}}$ & $8.06 \pm 0.44^{\mathrm{a}}$ \\
\hline
\end{tabular}

a.b.c Means \pm SD in the same letters followed by different column are significantly different $(P<0.05)$

TVFA : Total volatile fatty acids.

TN : Total nitrogen.

WSN : water soluble nitrogen.

NPN : Non protein nitrogen 


\section{Cheese texture profile analysis}

The mean values of the TPA parameters during the ripening period of the control and experimental cheeses are given in Table (3). Generally, lipase-treated UF cheeses exhibited considerable variations in the initial measurements (hardness, gumminess and chewiness) compared to the control cheeses. Within the inital 30 days of ripening, the experimental cheeses had significantly $(P<0.05)$ higher hardness values compared to the control UF cheese. This was found to be correlated with the lower moisture content of the lipase-treated UF cheeses. The hardness values of the control and experimental cheeses continuously decreased as the ripening period increased; this could be related to proteolysis. After 30 days of ripening, hardness values of lipase-treated UF cheeses did not change significantly. No significant difference existed between the control and treated cheese samples for cohesiveness and springiness values throughout ripening. The highest gumminess and chewiness values were observed in UF cheeses treated with lipase $(P<0.05)$. The decreasing level of moisture content in the cheeses may have produced the high chewiness values in these treatments.

In conclusion, addition of lipase increased hardness values of UF-Ras cheese significantly and when concentration of lipase increased, the hardness values also increased; indicating that lipase-treated cheese became more compact texture than control cheese. This could be related to the lipolysis process which in turn decreasing in plasticizing effect of fat in cheese texture. Decrease in the plasticizing effect of fat results in a compact texture, which could be related to the harder texture.

Table 3: The effect of adding microbial lipase on the textural properties (mean \pm SD) of UFRas cheese during ripening.

\begin{tabular}{|c|c|c|c|c|c|}
\hline \multirow[b]{2}{*}{ Parameters } & \multirow[b]{2}{*}{$\begin{array}{c}\text { Ripening } \\
\text { periods (days) }\end{array}$} & \multicolumn{4}{|c|}{ Treatments } \\
\hline & & Control & $\begin{array}{l}\text { Lipase } \\
\text { (50.000U) }\end{array}$ & $\begin{array}{c}\text { Lipase } \\
\text { (100.000U) }\end{array}$ & $\begin{array}{c}\text { Lipase } \\
(150.000 U)\end{array}$ \\
\hline \multirow{3}{*}{ Hardness (N) } & 30 & $73.35 \pm 1.34^{c}$ & $80.30 \pm 34.93^{\mathrm{ab}}$ & $100.55 \pm 1.48^{\mathrm{a}}$ & $81.80 \pm 24.80^{\mathrm{ab}}$ \\
\hline & 60 & $48.50 \pm 3.68^{a}$ & $33.40 \pm 3.25^{\mathrm{a}}$ & $70.55 \pm 12.37^{a}$ & $60.80 \pm 26.59^{a}$ \\
\hline & 90 & $37.45 \pm 8.41^{\mathrm{b}}$ & $23.89 \pm 1.68^{\mathrm{b}}$ & $38.85 \pm 12.94^{\mathrm{b}}$ & $44.55 \pm 08.56^{\mathrm{a}}$ \\
\hline \multirow{3}{*}{ Cohesiveness ( $)$} & 30 & $0.69 \pm 0.03^{\mathrm{a}}$ & $0.64 \pm 0.08^{\mathrm{a}}$ & $0.57 \pm 0.04^{\mathrm{a}}$ & $0.56 \pm 0.06^{\mathrm{a}}$ \\
\hline & 60 & $0.67 \pm 0.00^{\mathrm{a}}$ & $0.70 \pm 0.01^{\mathrm{a}}$ & $0.67 \pm 0.05^{\mathrm{a}}$ & $0.67 \pm 0.02^{\mathrm{a}}$ \\
\hline & 90 & $0.75 \pm 0.00^{\mathrm{a}}$ & $0.69 \pm 0.04^{\mathrm{a}}$ & $0.70 \pm 0.03^{\mathrm{a}}$ & $0.75 \pm 0.02^{\mathrm{a}}$ \\
\hline \multirow{3}{*}{ Springiness (mm) } & 30 & $3.70 \pm 0.27^{\mathrm{a}}$ & $3.44 \pm 0.11^{a}$ & $3.58 \pm 0.17^{\mathrm{a}}$ & $3.56 \pm 0.21^{a}$ \\
\hline & 60 & $1.72 \pm 0.11^{\mathrm{a}}$ & $1.85 \pm 0.28^{\mathrm{a}}$ & $1.76 \pm 0.02^{\mathrm{a}}$ & $1.97 \pm 0.06^{\mathrm{a}}$ \\
\hline & 90 & $0.90 \pm 0.07^{b}$ & $0.75 \pm 0.11^{\mathrm{b}}$ & $0.87 \pm 0.00^{\mathrm{b}}$ & $1.67 \pm 0.04^{\mathrm{a}}$ \\
\hline \multirow{3}{*}{ Gumminess (N) } & 30 & $50.61 \pm 1.84^{b}$ & $50.05 \pm 15.63^{\mathrm{ab}}$ & $57.15 \pm 4.17^{\mathrm{a}}$ & $46.35 \pm 18.17^{\mathrm{ab}}$ \\
\hline & 60 & $32.55 \pm 2.33^{a}$ & $23.35 \pm 1.91^{\mathrm{a}}$ & $47.20 \pm 11.46^{\mathrm{a}}$ & $40.75 \pm 19.16^{a}$ \\
\hline & 90 & $28.10 \pm 6.36^{\mathrm{b}}$ & $16.55 \pm 2.19^{b}$ & $27.05 \pm 7.85^{\mathrm{b}}$ & $33.41 \pm 04.24^{\mathrm{a}}$ \\
\hline \multirow{3}{*}{$\begin{array}{l}\text { Chewiness } \\
\text { (N.mm) }\end{array}$} & 30 & $187.25 \pm 12.95^{a}$ & $172.75 \pm 59.19^{a}$ & $204.40 \pm 04.95^{a}$ & $166.91 \pm 74.47^{a}$ \\
\hline & 60 & $55.82 \pm 07.46^{a}$ & $43.34 \pm 9.90^{a}$ & $83.06 \pm 21.08^{\mathrm{a}}$ & $80.86 \pm 39.85^{a}$ \\
\hline & 90 & $25.03 \pm 03.63^{\mathrm{b}}$ & $13.01 \pm 2.79^{b}$ & $23.55 \pm 06.90^{\mathrm{b}}$ & $55.79 \pm 04.75^{\mathrm{a}}$ \\
\hline
\end{tabular}

a.b.c. Means \pm SD in the same letters followed by different column are significantly different $(P<0.05)$ 


\section{Cheese sensory characteristics}

The mean sensory flavour and texture scores of UF-Ras cheeses are shown in Table (4). According to the statistical analysis, there are no significant differences were observed between control and treated cheese samples for the sensory scores (flavour and texture) during the first 15 days of cheese ripening and changed in significantly differences $\quad(P<0.05)$ thereafter.

Generally, the quality of UF-Ras cheese gradually decreased with increasing the rate of added lipase than the corresponding in control cheese. The quality of UF-Ras cheese treated with lipase $(50.000 \mathrm{U} / 15 \mathrm{~kg}$ UF milk) was similar to control ones during the ripening periods. At 60 days of ripening, a bitter taste was had noted in cheese treated with the higher concentration of the lipase enzyme. Certain panelists reported that the experimental cheeses seemed somewhat harder bodies than in the control cheese sample and a slightly bitter taste was detected in the cheese treated with high levels of lipase. At 90 days, the experimental UF-Ras cheeses had lower texture and flavour scores than that in the control UFRas cheese as a result of excessive bitterness. Kheadr et al. (2002) reported that lipase-treated cheeses had developed a soapy off-flavour after 2 and 3 months of ripening. Panelists preferred cheese samples containing lipase $50.000 \mathrm{U}$ because of their slightly better taste, texture and flavour.

There were significant differences in the total scores $(P<0.05)$ of the experimental and control UF cheeses. The most acceptable cheeses were the control cheeses, followed by Lipase $50.000 \mathrm{U} / 15 \mathrm{~kg}$ UF milk treated cheeses. The total scores of the experimental cheeses decreased at 90 days, probably due to the high level of lipolysis and poor textural properties.

Table 4: Effect of adding microbial lipase on the sensory scores (mean \pm SD) of UF-Ras cheese during ripening.

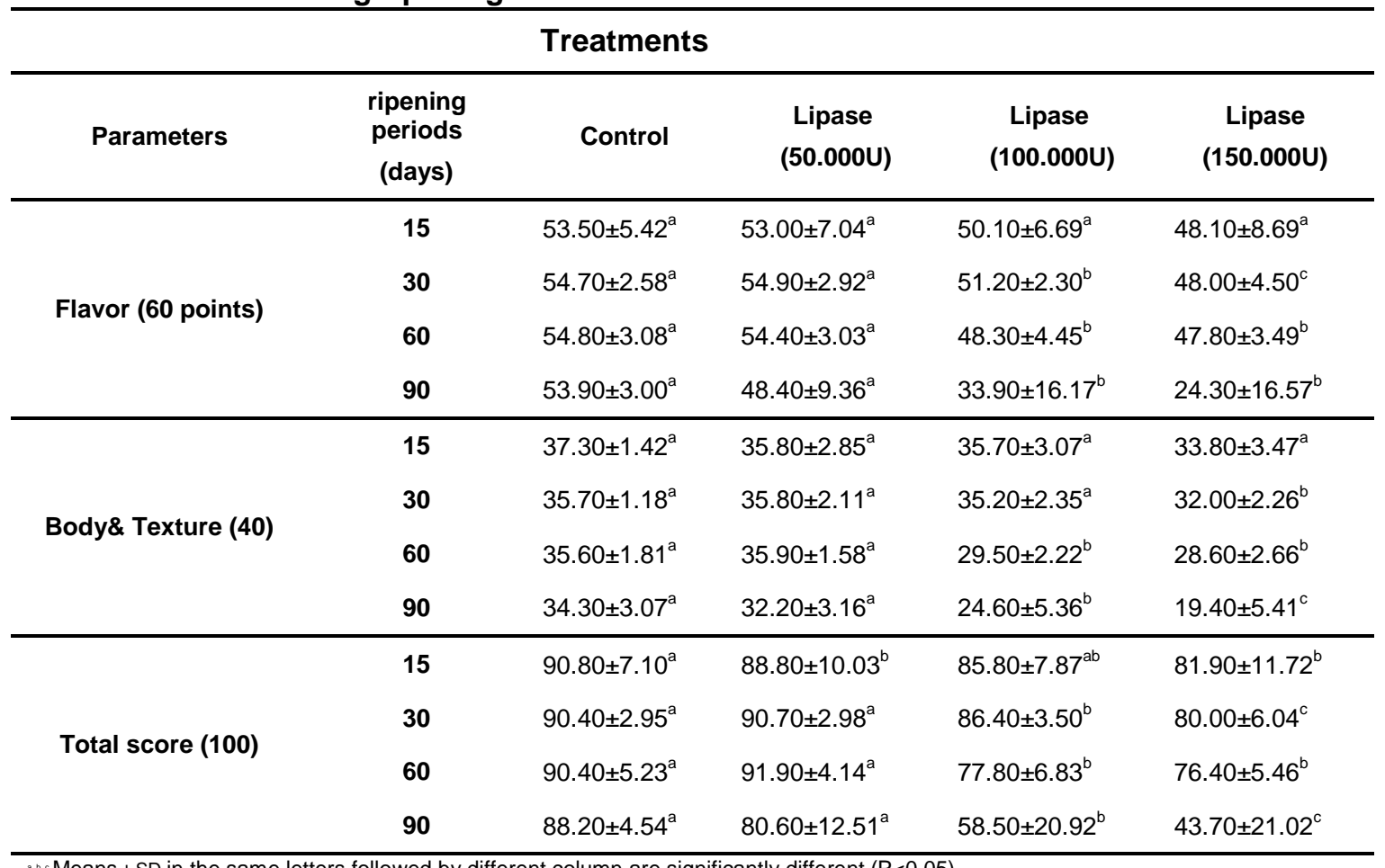

\footnotetext{
a., Means \pm SD in the same letters followed by different column are significantly different $(\mathrm{P}<0.05)$
} 


\section{CONCLUSION}

This study revealed that, the addition of microbial lipase to UF-Ras cheese milk, at $50.000 \mathrm{U} / 15 \mathrm{~kg}$ UF milk, could be reommended for accelerating the development of flavour and texture qualities in UF-Ras cheeses. However, this results indicated that to develop the quality of UF Ras cheese during the ripening period, more work is needed to determine the right dosage to adding lipase enzyme.

\section{ACKNOWLEDGEMENTS}

The authors are grateful to Prof. Dr. Nabil S. Abd Rabou for providing the lipase enzyme.

\section{REFERENCES}

Abou-zeid, N. A. (2015). The use of plant enzymes for ripening acceleration of ras cheese. The IIOAB Journal 6(2):15.

AOAC. (2005). Parameters of the profile texture analysis obtained from the yoghurt samples. (18th ed.), AOAC, Washington, USA.

Aravindan, R., P. Anbumathi, and T. Viruthagiri. (2007). Lipase applications in food industry. Indian Journal of Biotechnology 6(2):141.

Azarnia, S., N. Robert and B. Lee (2006). Biotechnological methods to accelerate Cheddar cheese ripening. Critical Reviews in Biotechnology 26(3):143-121.

El-Hofi, M., E. S. El-Tanboly and N. S. AbdRabou (2011). Industrial application of lipases in cheese making: A review. Int. J. Food Saf, 13, 293-302.

El-Shibiny, S., G. A. Mahran, H. F. Haggag, M. B. Mahfouz and M. M. El-Shiekh. (1990). Accelerated ripening of UF Ras cheese. In Brief Communications of the XXIII International Dairy Congress, Montreal, October 8-12, 1990, Vol. II.. International Dairy Federation..

El-Shibiny, S., G. M. Mahran, H. F. Haggag, M. B. Mahfouz and M. M. El-Sheik (1991). Manufacture and quality of UF Ras cheese. Food / Nahrung 35(10):1023-1028.

El-Soda, M., N. Ezzat, A. E. Salam and A. Khamis (1990). Acceleration of Ras cheese ripening. III. Evaluation of commercial enzyme mixtures. Egyptian Journal of Dairy Science 18(2):273-279.

El Neshawy, A. A., A. A. Baky and S. M. Farahat (1983). Enhancement of soft cheese flavour using animal lipase preparations. Food Chemistry 10(2):127121.

Federation, I. D. (1991). Rheological and fracture properties of cheese. IDF Bulletin 268.

Fox, P. F. (1993). Exogenous enzymes in dairy technology -a review. Journal of food biochemistry 17(3):173-199.

Hassan, A. A., G. Mahran, A. A. Ismai and M. A. El-Hofi (1996). Studies on Ras cheese ripening with enzymes addition. Egypt J. food Sci. 3:373-399.

Hernández, I., L. J. R. Barrón, M. Virto, F. J. Pérez-Elortondo, C. Flanagan, U. Rozas, and M. de Renobales. (2009). Lipolysis, proteolysis and sensory properties of ewe's raw milk cheese (Idiazabal) made with lipase addition. Food Chemistry 116(1):166-158.

Ismail, A. A., A. A. Hassan and M. A. El-Hofi (1996). Studies on Ras cheese ripening with enzymes addition. II. Application of bacterial proteases and lipases in acceleration ripening of Ras cheese. Egyptian Journal of Food Science 24(2):401-416.

Karami, M., M. R. Ehsani, S. M. Mousavi, K. Rezaei and M. Safari (2009). Microstructural properties of fat during the accelerated ripening of ultrafilteredFeta cheese. Food Chemistry 113(2):424-434.

Kheadr, E. E., J. C. Vuillemard and S. A. ElDeeb (2002). Acceleration of Cheddar cheese lipolysis by using liposomeentrapped lipases. Food Chemistry and Toxicology 67:485-491.

Kosikowski, F. (1966). Cheese and fermented milk foods. Ithaca, New york.

Omar, M. M., A. I. El-Zayat and M. Ashour (1986). Flavor enhancement, by lipase addition, of Ras cheese made from reconstituted milk. Food Chemistry 19(4):277-286.

Ozcan, T. and E. Kurdal (2012a). The effects of using a starter culture, lipase, and protease enzymes on ripening of Mihalic cheese. International Journal of Dairy Technology 65(4):585-593.

Ozcan, T. and E. Kurdal (2012b). The effects of using a starter culture, lipase, and protease enzymes on ripening of Mihalic cheese. International journal of dairy technology 65(4):593-585. 
تأثير إضافة الليبيز الميكرويي علي إسراع تسوية الجبن الراس الناتج من الترشيح الفائق

شيماء محمد حمدي ، هاني شعبان عبد المنطلب ، خالد عبد الحكم ، رتيبة أحمد بيومي ، محمود عبد الحليم دغيدي

قسم الألبان - كلية الزراعة - جامعة الفيوم دعائ

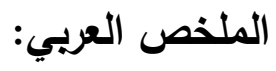

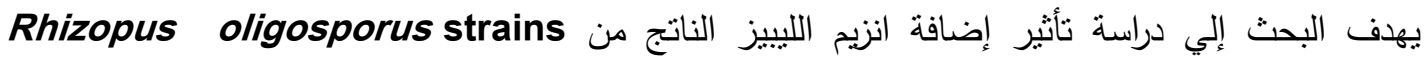
(صفر ، 50.000 ، 100.000 ، 150.000 وحدة / 15 كجم من اللبن المركز للإسراع تسوية الجبن الراس

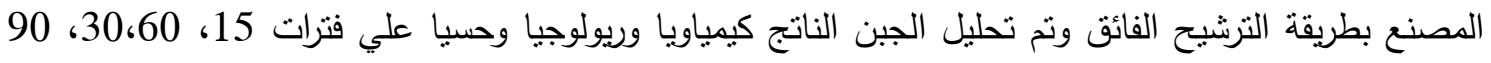
يوب النتبع درجات التسوية.

وتبين من الننائج المنحصل عليها أن انزيم الليبيز له تأثير معنوي علي التركيب الكيميائي للجبنحيث لوحظ زيادة معدل الحموضة وانخفاض \% الرطوبة في جبن المعاملات وزيادة ملوحظة في معدل التحليل البروتيني

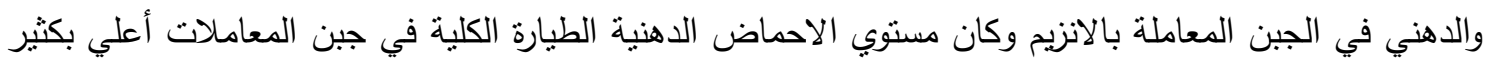

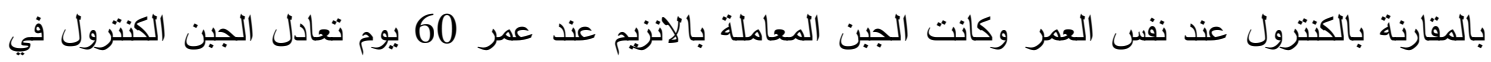

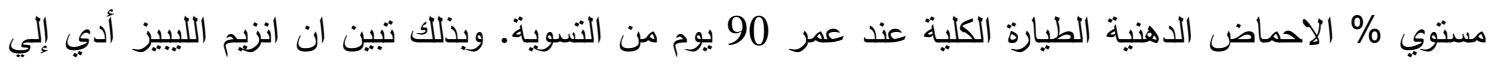
خفض حوالي 30\% من زمن التسوية. وكانت الجبن المعاملة بتركيزات عالية من الانزيم (100.000 ، harder texture مقارنة بالجبن الكترول مع تقدم فترات التسوية 150.000 وحدة) تتصف بتركية

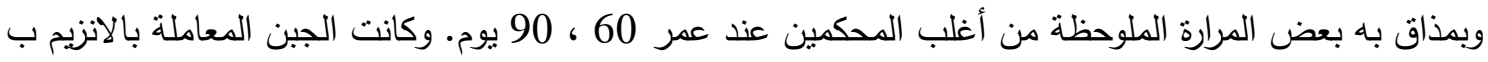
50.000 وحدة تثابة إلي حد ما الجبن الكنترول عند النحكيم عند عمر 60 يوم من التسوية. 